\title{
Renesanční ideál krásy: Tizianova Toaleta mladé ženy
}

\author{
Barbora Půtová \\ Ústav etnologie, Filozofická fakulta, Univerzita Karlova, nám. Jana Palacha 2, 11638 Praha 1, Česká republika
}

Do redakce doručeno 20. záŕí 2020; k publikaci přijato 18. listopadu 2020

\section{RENAISSANCE IDEAL OF BEAUTY: TITIAN'S WOMAN WITH A MIRROR}

\begin{abstract}
This paper deals with art-scientific description, analysis and interpretation of Titian's canvas Woman with a Mirror (1512-1515) from the Prague Castle Picture Gallery (Obrazárna Pražského hradu). The paper applies iconographic approach to the interpretation of motifs as well as to historic, fine art and literal sources of inspiration and influences. Attention is paid particularly to the motifs of the mirror, reflection and the Renaissance ideal woman in the context of the period fashion, body care and corporal beauty. In this context, the paper also describes and analyses the creation of the female half-length portrait as artistic innovation in the works by Venetian masters from the first third of the 16th century. The paper does not omit other versions and variations of this canvas from Titian's workshop or painters who followed up with their works Woman with a Mirror. In the last part, the paper presents the acquisition history of the canvas and its occurrence in the Rudolf II' collection at the Prague Castle.
\end{abstract}

KEY WORDS Titian; Renaissance; toilet; mirror; portrait; woman; ideal of beauty

\begin{abstract}
ABSTRAKT Předmětem studie je uměnovědná deskripce, analýza a interpretace Tizianova plátna Toaleta mladé ženy (1512-1515) z Obrazárny Pražského hradu. Ve studii je uplatněn ikonografický př́stup k výkladu konkrétních motivů, včetně postižení historických, výtvarných i literárních předloh a vlivů. Pozornost je kladena zejména na motiv zrcadla, zrcadlení a renesanční ideál ženy v kontextu dobové módy, péče o tělo a tělesný půvab. $\mathrm{V}$ této souvislosti je popsán a analyzován také vznik ženského polovičního portrétu jako výtvarné inovace v dílech benátských mistrů první třetiny 16. století. Studie neopomíjí ani další verze a variace tohoto plátna z okruhu dílny Tiziana nebo malíře, kteří ve své umělecké tvorbě navázali na obraz Toaleta mladé ženy. V závěru studie je prezentován akviziční osud plátna a jeho výskyt ve sbírce Rudolfa II. na Pražském hradě.
\end{abstract}

KLÍČOVÁ SLOVA Tizian; renesance; toaleta; zrcadlo; portrét; žena; ideál krásy

Toaleta mladé ženy (1512-1515) od italského malíře Tiziana (1488-1490) se nachází v Obrazárně Pražského hradu (Neumann 1976). Plátno je reprezentativní ukázkou renesančního ženského portrétu, jehož prostřednictvím umělci „představovali svého vlastního genia“ (Goffen 1997, 17). Tizian na plátně zachytil ideál ženské krásy 16 . století, včetně jemnosti ženských forem a vyjádření měkkosti pokožky, kterou charakterizuje vlhký lesk i záře. Tizian dokázal uplatnit benátskou zálibu v barevnosti za užití subtilní hry světla a stínu. Mladá žena je oděna $\mathrm{v}$ šatech a bílé až šedě stínované košili, jejíž linka těsného a nabíraného živůtku, zabořená do kůže, zdůrazňuje hebkost bledé a místy až namodralé pokožky, hluboké dekoltáže paží a dekoltu. Světlost pokožky i košile vytvárí v divákovi pocit, že se postava ženy nejen odráží od tmavého pozadí, ale také z něj vystupuje. Košili překrývají šaty se čtvercovým výstřrihem bez rukávů, které doplňují široké a nařasené rukávy košile, která s nedbalou elegancí odhaluje levou paži. Šaty jsou nabírané v pase, kolem něhož je svinutý pruh hedvábí, sloužící jako pásek svázaný v uzlu a nařasený na koncích. Šaty tmavě zelené barvy, vyrobené pravděpodobně z grogrénu nebo kepru, představovaly jednoduchý domácí oděv. $\mathrm{V}$ přítomnosti návštěvy se žena většinou oblékla ještě do dalších šatů nebo županu. Takový kus oděvu, patrně modrý šál, překrývá zápěstí ženy na jiné verzi plátna Toaleta mladé ženy z Louvru. Tizian zachytil ženu v okamžiku, kdy si rukou přidržuje pletenec zvlněných plavých vlasů rusého odstínu, jenž byl v Benátkách předmětem obdivu. Další kadeře vlasů jí spadají na záda. Její pozdvihnutý ukazováček směřuje $\mathrm{k}$ obličeji. 


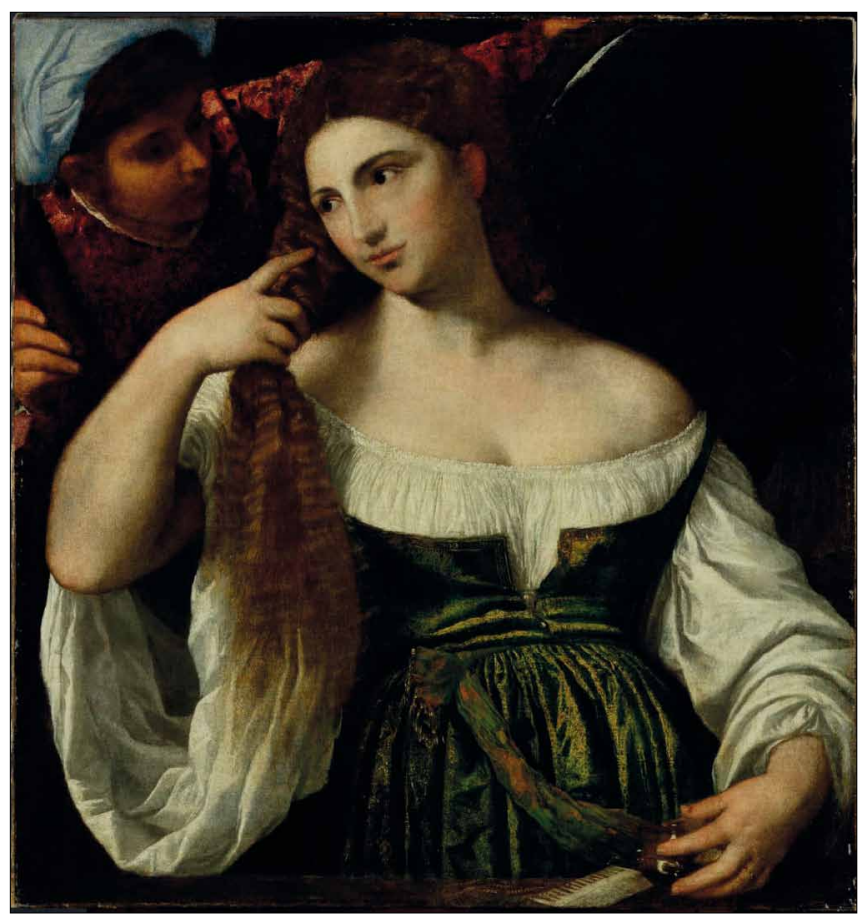

Tizian, Toaleta mladé ženy (1512-1515). Olejomalba, $83 \mathrm{~cm} \times 79 \mathrm{~cm}$. (c) Obrazárna Pražského hradu, Praha.

Jedná se o okamžik nanášení parfému, masti nebo oleje. Prst druhé ruky totiž žena pokládá na lahvičku stojící na poličce se záměrem nanést kapku na pokožku. Kromě lahvičky jsou zde jako součást zátiší odložený hřeben a stužka. Lahvička na parfém, mast nebo olej jsou analogií $\mathrm{k}$ malbě, která je také míchána a aplikována (Pardo 1993). Žena má na plátně zkroucené předloktí a loket nepřirozeně vzdálený od ramene. Ruka je zde součástí Tizianovy vizuální iluze, jež v jeho vlastní imaginaci maluje postavu ženy. Na prsteníku levé ruky je navlečen jednoduchý prsten, patrně zásnubní, vyjadřující ženu alegoricky stojící před volbou. Na verzi plátna $\mathrm{z}$ Louvru je prsten navlečený na malíčku, a navíc ozdoben kamenem. V tomto př́padě se jedná o vyjádření jedinečnosti; žena může být svobodná nebo být milenkou muže. Některá plátna jsou považována za portréty kurtizán, čemuž by odpovídaly skvělost oděvu a šperků i dekoltáž. Je však obtížné přijmout zobecnění, „že ideální krása kombinovaná s erotickou pritažlivostí $v$ mnoha těchto portrétech měla za di̊sledek (...), že je někteři historici prohlašovali za znázornění kurtizán." (West 2004, 150) Stejně tak šperky, prsteny, perly a květiny mohou být doklady toho, že se jedná o nevěsty. Posláním těchto atributů bylo sloužit jako iniciace a inspirace smyslného vztahu očekávané nové ženy. Prsty ženy ve tvaru $\mathrm{V}$ na plátně Toaleta mladé ženy jsou aluzí na Venuši, př́padně na ctnost, anebo pouze výrazem půvabu a uhlazenosti.

Vysoce individualizovaná žena pohliží s klidným výrazem ve tváři do zrcadla, které jí přidržuje mladý muž vystupující ze stínu, možná snoubenec, manžel, sluha nebo milenec. Několik málo mužů mohlo být $\mathrm{v}$ renesanční společnosti účastno intimní úpravy ženy v ložnici. Zpravidla to byli holič nebo

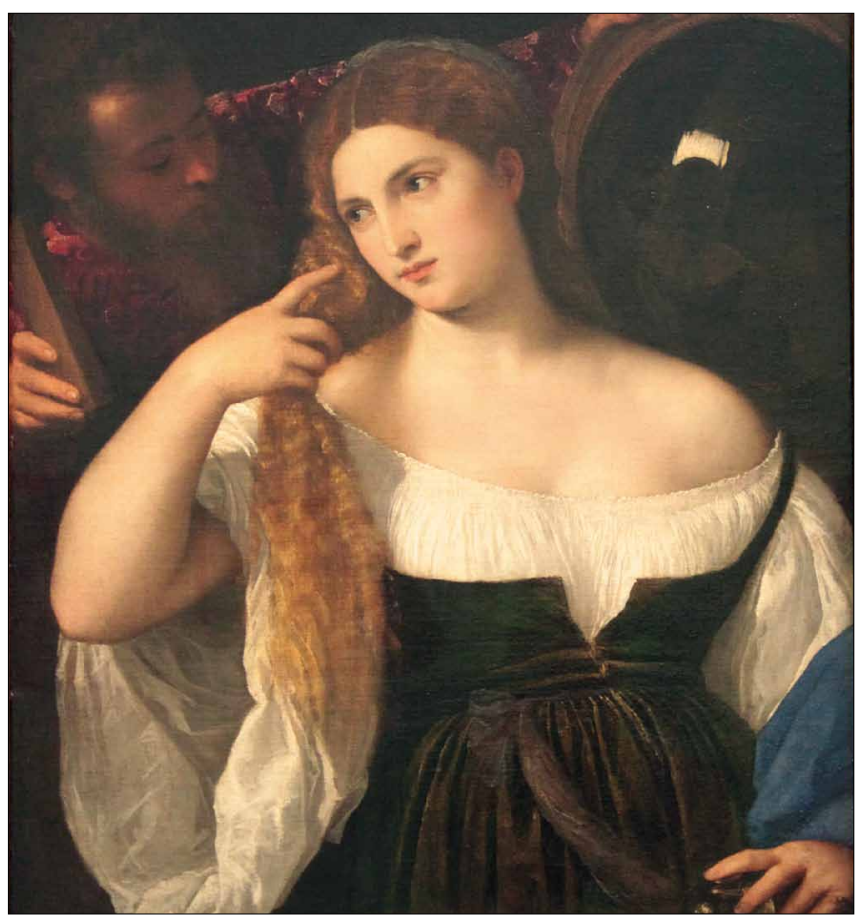

Tizian, Toaleta mladé ženy (kolem 1515). Olejomalba, $99 \mathrm{~cm} \times 76 \mathrm{~cm}$. (c) Musée du Louvre, Paříž.

umělec, kdož měli povoleno nosit sako. Mladý muž na plátně Toaleta mladé ženy je oděn v brokátově červeném saku a jeho hlavu zdobí světle modrý turban. Kromě menšího obdélníkového zrcadla zepředu přidržuje mladý muž druhé oválné vypouklé zrcadlo zezadu. Toto temné zrcadlo však nic neodráží. Symbolizuje smrt a je objektem spojovaným s dáblem. Držením zrcadla mladý muž určuje i průběh prováděné toalety (Hagen - Hagen 2002). Zrcadlo, hřeben a lahvička jsou využity jako typická šlechticí proprieta, duplikující krásu ženského těla, která znásobuje senzualitu malířského díla (Melchior-Bonnet 2001). Identifikace ženy na obraze zůstává doposud neobjasněna. Zpravidla je uváděna jako Laura Dianti (1480-1573), milenka ferrarského vévody Alfonse I. d'Este (1476-1534), nebo Isabella Boschetti, milenka mantovského vévody Federica II. Gonzagy (1500-1540). Tizian Lauru Dianti zachytil také na jiném portrétu z období po roce 1520 . Jako předloha a inspirace prricházela $\mathrm{v}$ úvahu také Violante, dcera italského malíře Palma Vecchio (1480-1528) a potenciální Tizianova milenka, již ztvárnil na stejnojmenném plátně kolem roku 1515.

Dvě zrcadla zachycená na plátně vyjadřují odlišné mody vnímání - světské a duchovní. Navíc kruh v renesanci zastupoval nebeská tělesa, zatímco obdélník tělesa pozemská, a to s ohledem na čtyři body kompasu i čtyři živly. Kulaté zrcadlo bylo spojováno se ženou, Měsícem a katoptromantií (věštba). Žena nemusí v zrcadle pozorovat pouze svou vlastní tvář, ale může do něj projektovat obraz budoucnosti. Alegoricky krása pohlíží na sebe do zrcadla, aby zde náhle spatřila pomíjivost a smrt. Je zde umělecky vyjádřena myšlenka podobná motivu na dalším Tizianově plátně Vanitas (kolem 1515). Zrcadlo 


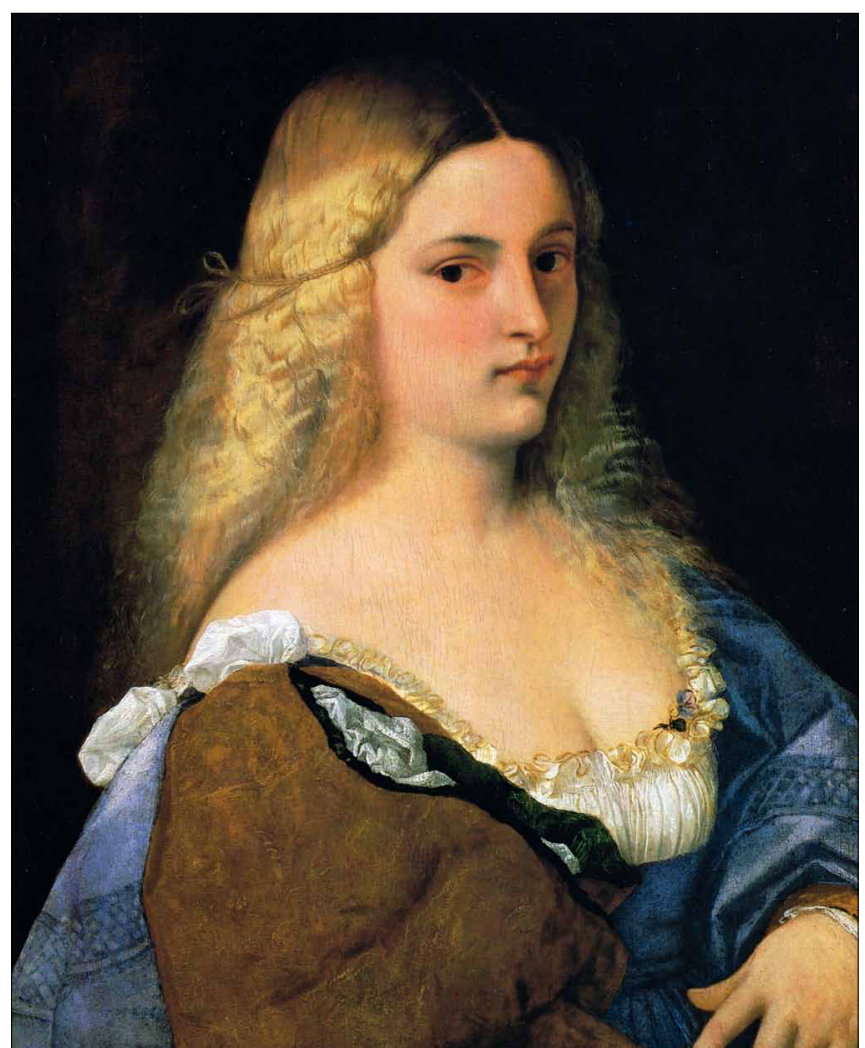

Tizian, Violante (kolem 1515). Olejomalba, $64,5 \mathrm{~cm} \times 50,8 \mathrm{~cm}$. C Kunsthistorisches Museum Wien.

je atributem moudrosti i pomíjivosti a marnosti. Alegorické zobrazení mladé ženy může vést k obrácení pozornosti pouze $\mathrm{k}$ vlastní osobě. Zrcadlo se tak stává výlučnou oblastí soustředění vlastního obdivu a středobodem, jenž přitahuje a poutá zrak ženy. Cesare Ripa (kolem 1560-kolem 1622) v díle Iconologia (1593) vysvětluje shlížení pýchy v zrcadle tak, že „pyšní lidé se vždy považuji za hodné a krásné a odmítají si připustit jakoukoli nedokonalost“ (Maser 1991, 126). Žena je neschopná odolat vábení půvabů a krásy vlastního těla, které je však dříve nebo později předurčené $\mathrm{k}$ zániku a rozkladu.

V období renesance obraz zrcadla a odraz ženy vstupoval i do milostné poezie. Např́ílad italský básník Francesco Petrarca (1304-1374) adresoval výčitky zrcadlu, které působením svého odrazu ubíralo půvaby tváře jeho milované Laury. „Já však spíš krutá zrcadla dnes káři,

že vaše zraky krásou unavily.

Před nimi láska prosebnice není

že němý stín a musí mlčeti,

když sama jste cíl svého roztoužení." (Petrarca 1965, 29)

Zobrazení ženy se zrcadlem v sobě skrývá poselství zvěstující časovou omezenost lidské existence, směřování k neodvratné konečnosti samotného bytí a jednoznačnosti smrti. Směrodatné bylo v tomto př́ípadě vědomí dočasnosti existence člověka na tomto světě, proto i zrcadlo svým letmým odleskem lidské př́tomnosti pouze smrtelnost potvrzovalo. Faktor pomíjivosti podporovala také jeho křehká forma, jejíž destrukce

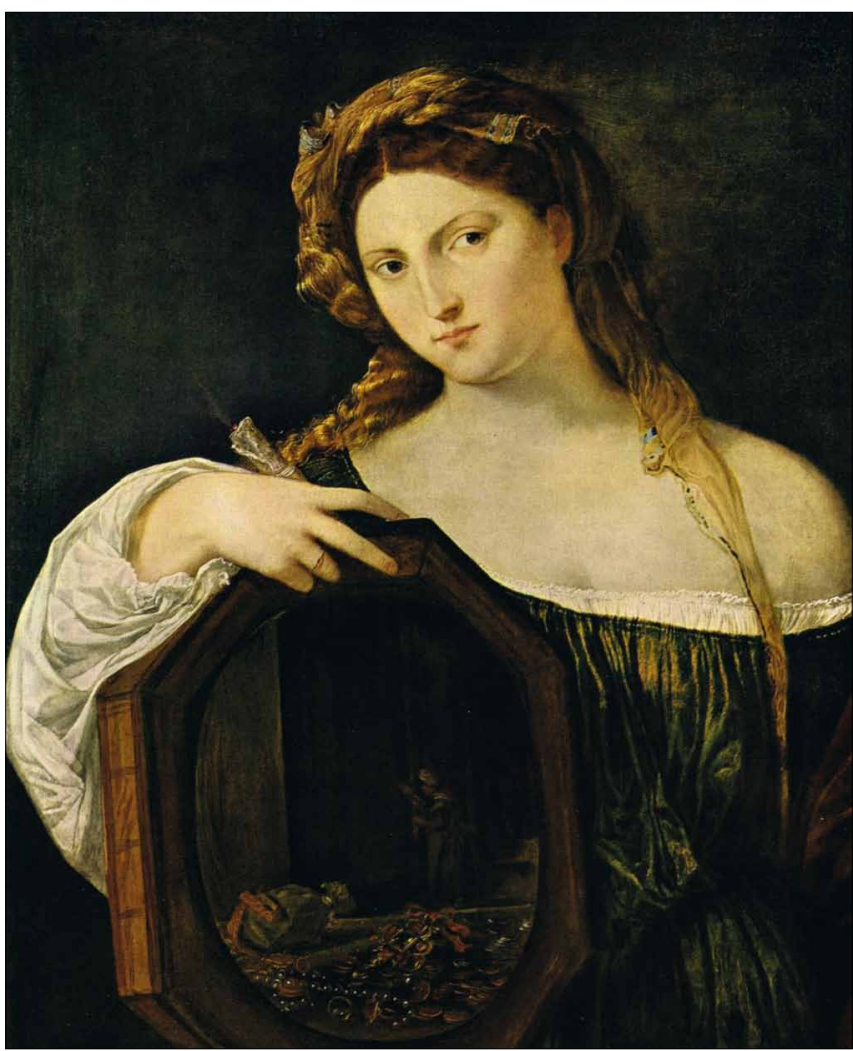

Tizian, Vanitas (kolem 1515). Olejomalba, $97 \mathrm{~cm} \times 81,2 \mathrm{~cm}$. (C) Alte Pinakothek, Mnichov.

reprezentovala symbolický rozpad pozemského světa, který se odráží na reflexním povrchu zrcadla. Současně také vytvářela jistý vizuální odkaz na křehkou zranitelnost lidského života (Christel 2011).

Nárůst maleb s motivem zrcadla a zrcadlení je možné v díle italských mistrů, zejména však Benátčanů, zaznamenat od počátku 16. století. „Zrcadla a zrcadlící se obrazy hrají düležitou roli $v$ benátské malbě 16. století, kdy umělci využívali vlastnosti olejových barev při zkoumáni textury, zrcadlících se forem a světla." (Tinagli 1997, 141) Východiskem těchto pláten se stal bohatě vyřezaný nábytek restello, v jehož středu se nacházelo zrcadlo a po stranách obrazy (Goffen 1999). Cílem využití zrcadel v obrazové kompozici bylo vyvolat hmatový dojem tělesnosti. Zrcadlo je magickým předmětem $\mathrm{v}$ moci ženy, zjevujícím v jedinečné chvíli její odraz a umožňujícím odhalit místa, která by za normálních okolností nemohla sama zkontrolovat a prohlédnout. Žena využívá nejenom reflexivity, ale také reflexe ke kontrole svého zevnějšku. Toto odhalené tajemství však náleží pouze jejímu zraku. Její soustředěný pohled působí dojmem zkoumavého sledování vlastní tváře a zamyšleného pátrání, jež dosahuje charakteru psychologické introspekce. Zrcadlo nemůže odrážet krásu jejího těla, ale pouze její tvář během posledních úprav. Zrcadlo figuruje jak v oblasti výtvarného umění jako symbolický motiv, tak i v roli praktického prostředku sloužícího k toaletě ženy. Umožňuje totiž šlechtění jejího těla, úpravu vlasů a tváře i optickou 
kontrolu dosaženého výsledku (Bertamini - Latto - Spooner 2003). „Chytré zrcadlo, které určuje a kontroluje krásu.“ (Tour d'Albenas 1953, 353) Zrcadlo se stalo důvěrným společníkem zkrášlování i očisty těla a často také jediným svědkem intimních momentů ženy. Zrcadlo představovalo luxusní předmět, na nějž měli v období renesance výrobní monopol ve svých rukou Benátčané. Zrcadla se odtud vyvážela nejenom do Evropy, ale i na Východ. Zrcadlo nebylo pouze symbolem marnivosti, ale tvořilo poměrně běžnou praktickou součást výbavy žen vyšších kruhů (Melchior-Bonnet 2001). „Žena při toaletě znázorňuje daleko více než sebe samou: ztělesňuje ovládanou přirozenost, tajemství svádění a je prototypem krásy osvobozené od nepredvídatelnosti práce. " (Melchior-Bonnet 2001, 214)

Toaleta mladé ženy odpovídá představě renesančního ideálu ženy a jejímu přirovnání $\mathrm{k}$ antické váze „s dlouhým krkem vystupujícím jemně z ramen, je váza jako žena s dlouhým štíhlým krkem a širokými pưvabnými rameny" (Cropper 1976, 374). Ideál renesanční ženské krásy charakterizovala 1 . bílá plet, 2. světlé dlouhé vlasy zlatavých až hnědý odstínů, 3. velké a mírně vystupující oči, 4. upravované obočí plné ve středu a zužující se u konců, 5. světlá oční víčka s prosvítajícími žilkami, 6 . červené líce, 7. úzký nos k obočí, 8. malá ústa, 9. dlouhý krk, 10. vysoké čelo, 11. pěstěné ruce. Znázorněná žena je reálnou živoucí bytostí, patrně namalovaná podle konkrétního modelu. Model renesanční ženy předložil italský diplomat Baldassare Castiglione (1478-1529) v knize Dvořan (1527). „Neuvědomujete si, oč pritažlivější je žena, která když se lićí, lící se jen docela nepatrně a skromnè, takže to málokdo pozná, nežli ta, co si zmaluje obličej, až to vypadá, jako by na ném nosila masku, neodvažuje se zasmát, aby si nátèr nezničila (...) A že se ze všech nejvíc líbí žena (pravda ne ošklivá), na které každý jasně vidí, že nemá na sobě žádné šminky, není ani príliš bledá, ani príliš červená, ale má prirozenou barvu, jen občas se ze studu nebo z rozpaků nevinně zardí (...) že se pohybuje volně a přirozeně a nedává najevo tu prepečlivou snahu být krásná?" (Castiglione 1978, 78) „Totéž platí o rukou: jsou-li jemné a pěkně utvářené a ukazuje-li je dáma nezakryté ve chvíli, kdy je $k$ něčemu potřebuje (...) působi rozkošně." (Castiglione 1978, 79)

Ideálu renesanční krásy žena dosahovala prostřednictvím kosmetických prostředků. Základní ingredienci make-upu tvořila cerusa (uhličitan olovnatý), jež se míchala s dalšími př́sadami do odstínu alabastru. Aplikovala se na obličej, krk a dekolt. Červená, odstíny karmínové, světle červené až růžové, sloužila na líčka a rty. Tužky se užívaly k dotvarování pinzetou vytrhaného obočí. Ženy si však vytrhávaly a holily také vlasovou linii za účelem zvýšení dojmu vysokého čela. Vlasy se odbarvovaly (hydroxid sodný nebo draselný) a barvily; užívala se hena a další rostlinná barviva z kurkumy nebo rebarbory (Angeloglou 1970; Gunn 1973). V období renesance představovala prosperující řemeslo výroba vonných olejů, pomád, vodiček a parfémů $\mathrm{z}$ alkoholu. Mezi populární vůně patřila neroli (silice $\mathrm{z}$ květů hořkého pomerančovníku), damašská růže, levandule a myrha (Genders 1972).

Ženský poloviční portrét představoval inovaci v dílech benátských mistrů první třetiny 16. století. Do této doby kvantitativně převyšovaly mužské historické portréty. Zdůvodnění lze

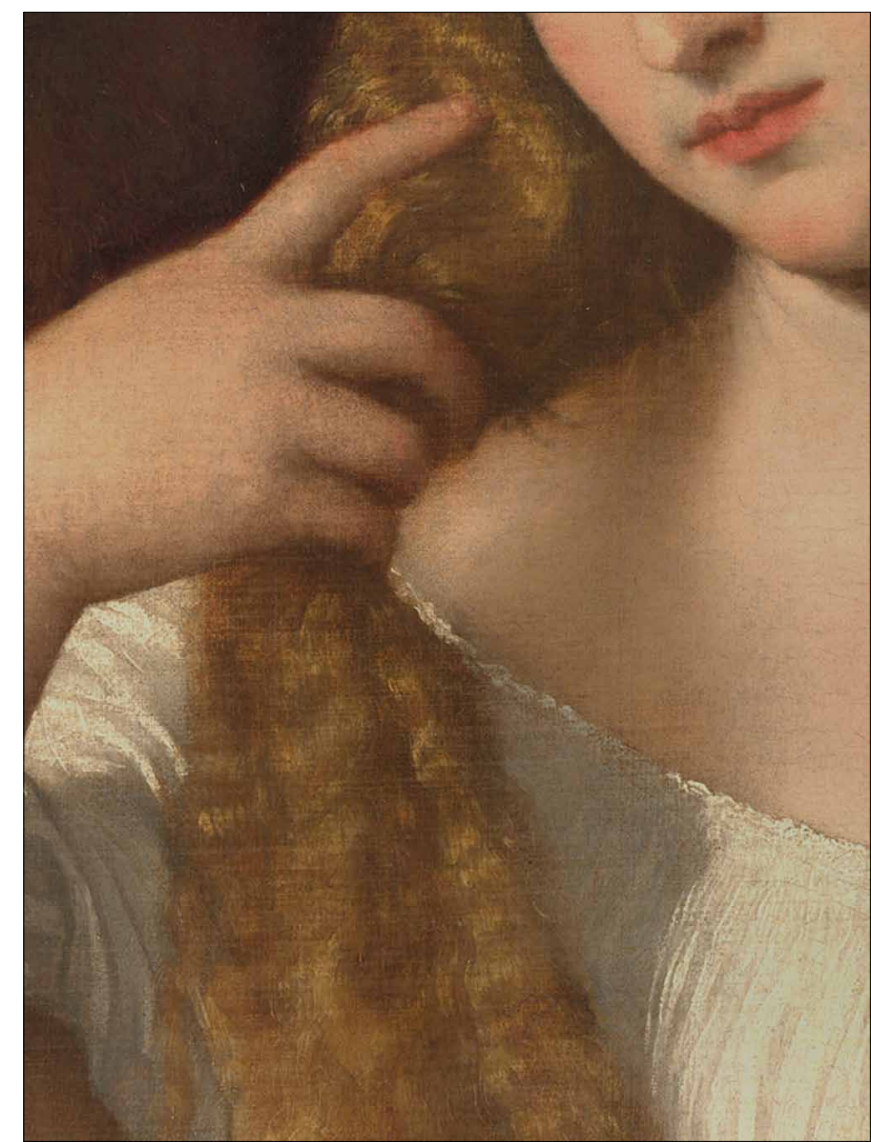

Tizian, Toaleta mladé ženy (kolem 1515), detail prstů, vlasů a živůtku. Olejomalba, $99 \mathrm{~cm} \times 76 \mathrm{~cm}$. (C) Musée du Louvre, Paříž.

hledat v benátské oligarchii, která vyřazovala ženy z vládnoucí role (Chojnacki 1990). Dokonce plátna manželek dóžat se dochovala sporadicky, a to většina $z$ období po polovině 16 . století, kdy se ženské portréty objevily ve velkém počtu. Od roku 1422 však Benátská republika vydávala kvưli udržení oligarchie dekrety, jež stále více podporovaly ženy ze šlechtických rodin. Aby byla zaručena čistota vlády patriciátu, Benátky zabezpečily materiální potřebu žen prostřednictvím nových zákonů dědičnosti. Ženské portréty měly význam v dynasticky strukturovaném městském státě a sloužily $\mathrm{k}$ potvrzení nároku dědičné moci. Manželé začali zanedbávat své profesní povinnosti v obchodní nebo politické oblasti. Nedostatek zachovaných historických portrétů šlechtičen, dcer, nevěst nebo bohatých manželek vyrovnávají idealizované portréty. Tento typ zahrnuje různé formy oslavy ženské krásy (Cropper 1986; Simons 1995). Mnoho atributů je spojeno s biblickými postavami, jako byly např́klad Judita a Salome, nebo mytologickými postavami, zejména Florou a Venuší. Realistické rysy portrétů jsou často potlačeny, ačkoliv individuální rysy mohly být do malby začleněny na žádost zadavatele. Senzibilita je vyjádřena půvabnými gesty, rafinovaným postojem, nakloněním hlavy, polopostavou ženy z profilu anebo zezadu. Tizianova korespondence naznačuje, že pravděpodobně zaměstnával ženy jako modely. Jeho idealizované portréty tak odráží a zachycují realistické rysy (Brown - Ferino-Pagden 2006). 


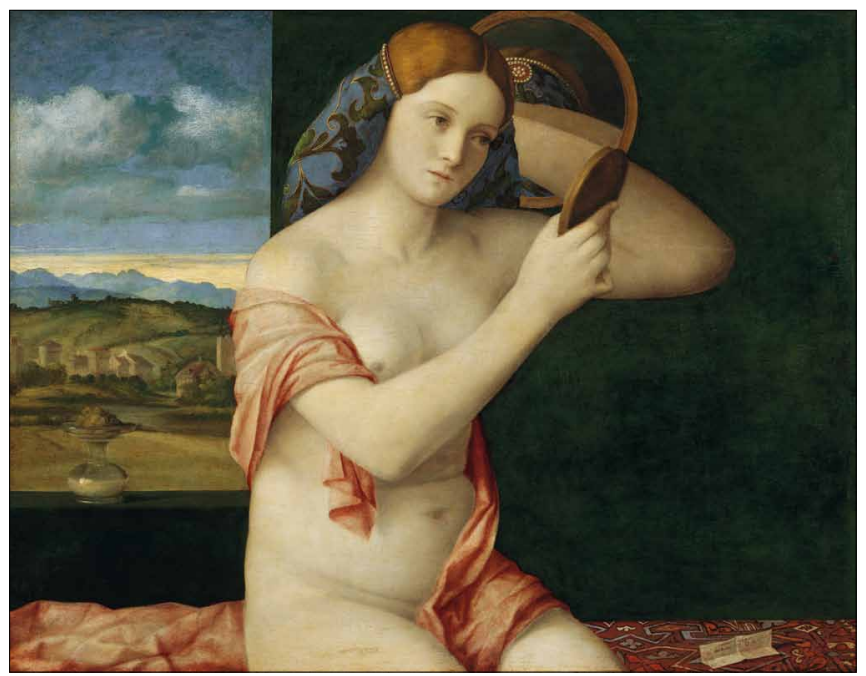

Giovanni Bellini, Toaleta mladé ženy (1515). Olejomalba, $60,3 \mathrm{~cm} \times 80,4 \mathrm{~cm}$. (c) Kunsthistorisches Museum Wien.

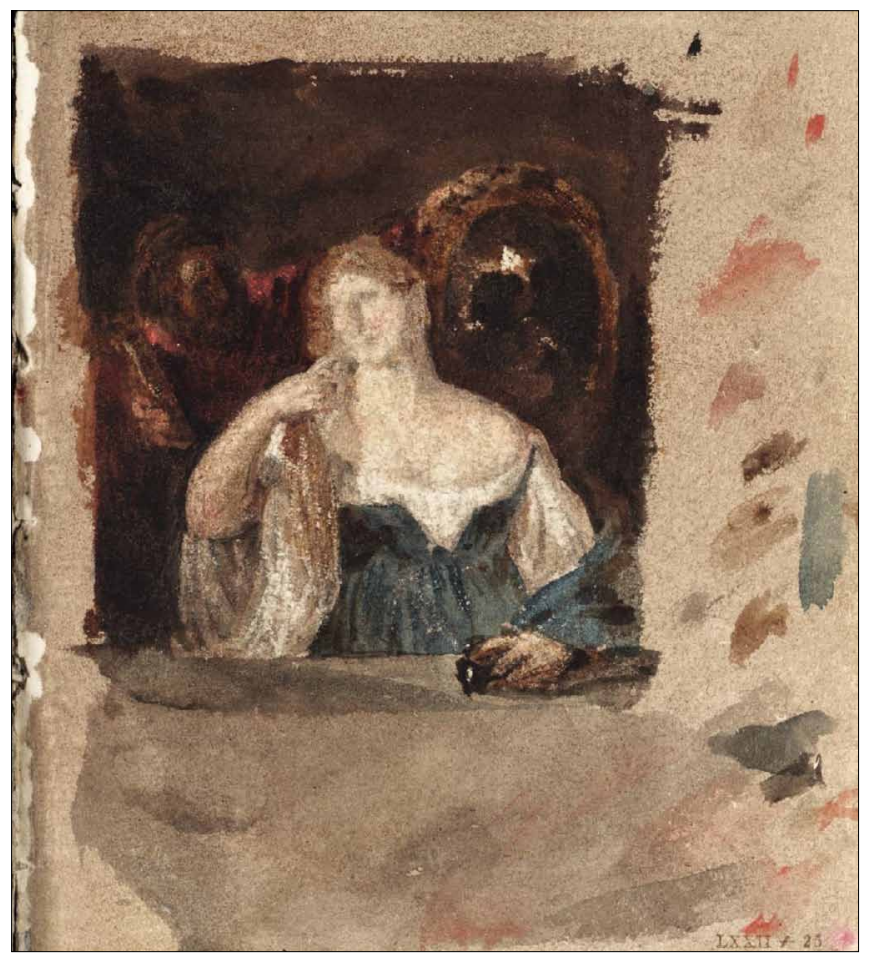

William Turner, Tizian a jeho milenka (1802). Skicář Studie v Louvru, akvarel a tužka, $12,8 \mathrm{~cm} \times 11,4 \mathrm{~cm}$. (C) Tate Gallery, London.

Tizian v provedení plátna Toaleta mladé ženy a umístění ženy mezi dvěma zrcadly následoval malířského vzoru svého učitele Giovanni Belliniho (1430-1516) na jeho posledním nebo jednom z posledních pláten Toaleta mladé ženy (1515). Využití barevné kombinace zelené a červené zde odpovídá Tizianově giorgionovskému období. Modrá se na plátně projevuje pouze ve světlém odstínu, zatímco v pozdější fázi zastupuje zelenou a stává se vedle červené primární barvou. Objemová skladba se spojuje s benátským citem pro kolorit (Neumann 1966). Tizian na plátně Toaleta mladé ženy navázal a rozvinul de-

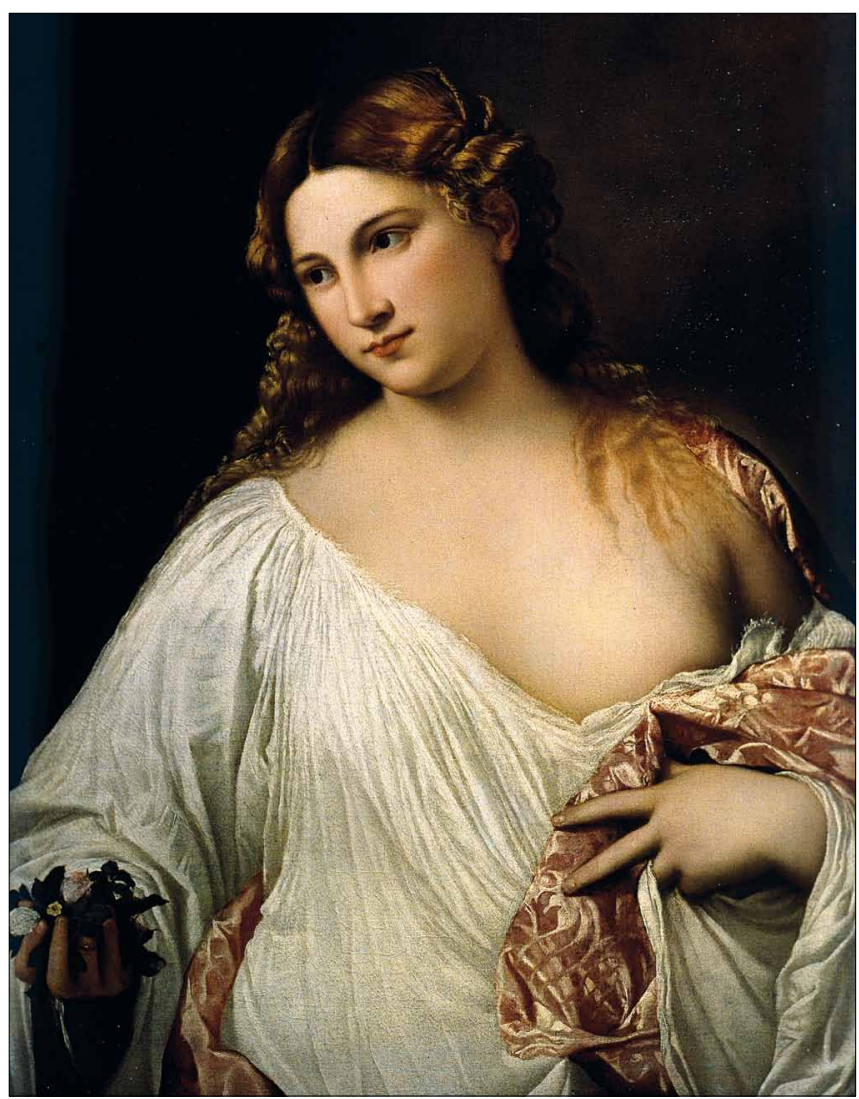

Tizian, Flora (kolem 1515). Olejomalba, $79 \mathrm{~cm} \times 63 \mathrm{~cm}$. (C) Galleria degli Uffizi, Florencie.

batu o srovnání malířství a sochařství. Konvexním zrcadlem umožňuje totiž divákovi obdivovat záda ženy a pokoj, v němž se žena nachází. A stejně jako sochu lze ženu sledovat $\mathrm{z}$ několika bodů a úhlů pohledu. Tizianovo provedení prstů ruky je možná inspirováno plátnem Autoportrét (1500) německého malíře Albrechta Dürera (1471-1528). V moderním umění zpodobňoval studie rukou podobným způsobem španělský malír Pablo Picasso (1881-1973). Plátno Toaleta mladé ženy inspirovalo také britského malíre Williama Turnera (17751851), v jehož náčrtníku se dochovala studie Tizian a jeho milenka (1802). V mnoha případech však jako př́má inspirace nesloužilo plátno z pražské sbírky, nebot’ umělci navazovali na další variace tohoto díla dnes připisovaná jeho dílně. Jmenovitě Toaleta mladé ženy (kolem 1515) v pařižském Louvru, Toaleta mladé ženy (po roce 1520) v Museu Nacional d'Art de Catalunya v Barceloně a Toaleta mladé ženy (kolem 1555) v National Gallery of Art ve Washingtonu (Wethey 1975). Motiv zrcadla a zrcadlení Tizian uplatnil také na dalších plátnech, např́klad Venuše se zrcadlem z období kolem roku 1550 a následně kolem roku 1555 (Meyers 2002). Jemnost tváře mladé ženy, natočení šíje a pozice těla však odpovídají ztvárnění na jeho dalších plátnech Flora a Salome, které vznikly ve stejném období (Kaminski 1998).

Plátno Toaleta mladé ženy tematicky odpovídá sbírce císaře Rudolfa II. Habsburského (1552-1612), který se natrvalo usadil v Praze v roce 1583 a setrval zde až do své smrti v roce 1612 . 


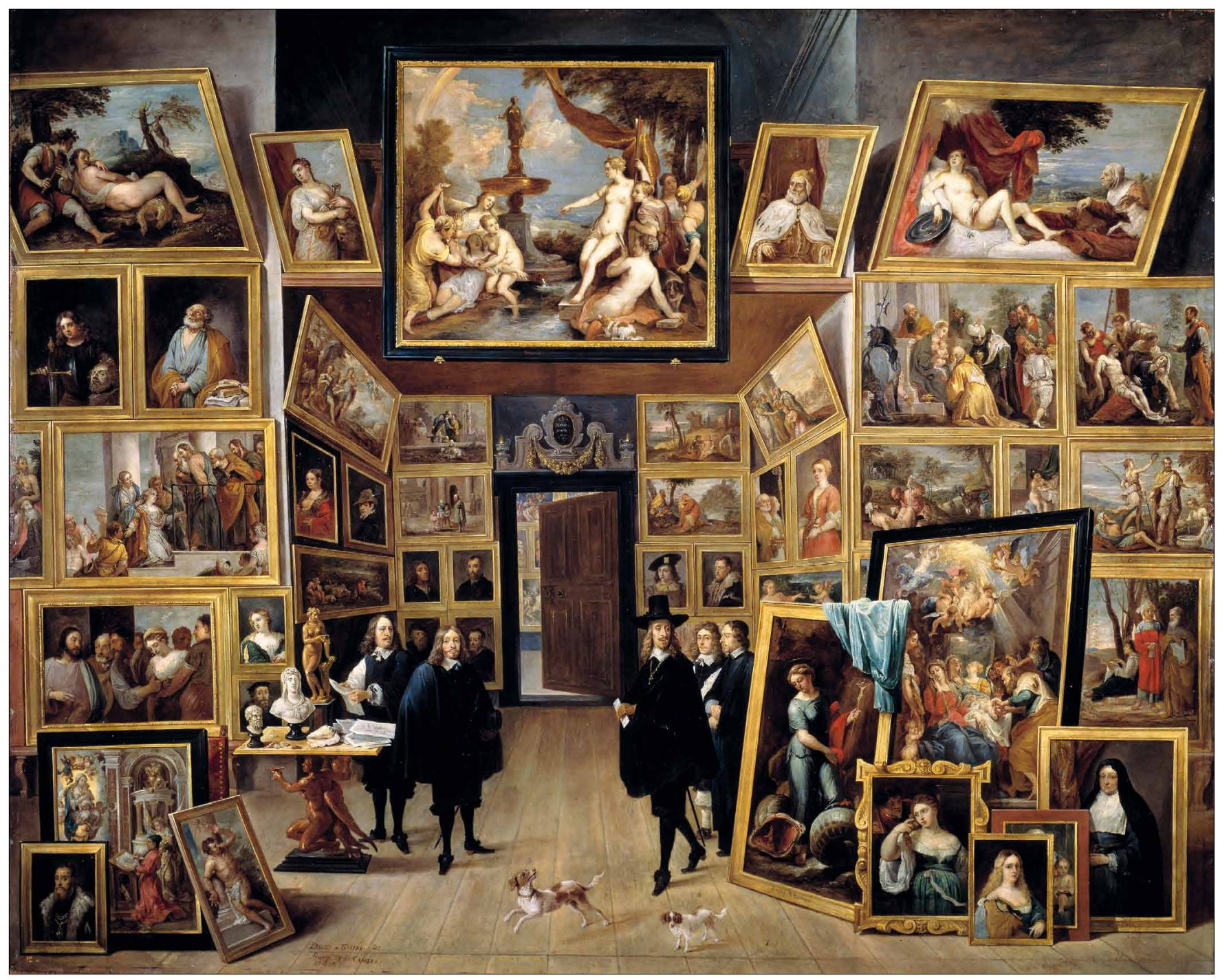

David Teniers mladší, Leopold Vilém ve své obrazárně v Bruselu (kolem 1651). Olejomalba, $106 \mathrm{~cm} \times 129 \mathrm{~cm}$. C Museo del Prado, Madrid.

Rudolfova záliba v umění odpovídala zájmu jeho předků a výchově. Jeho otec císař Maxmilián II. Habsburský (1527-1576) patřil $\mathrm{k}$ mecenášům umění. Dalším vzorem $\mathrm{v}$ oblasti sběratelství byl pro Rudolfa jeho strýc, španělský král Filip II. (1527-1598), na jehož madridský dvůr byl poslán na výchovu. Ve Španělsku poznal Filipovy sbírky, v nichž byl osloven obrazy italských mistrů včetně Tiziana. Za vlády Rudolfa II. lze Prahu přirovnat $\mathrm{k}$ Parnasu. Císař se zaměřoval zejména na alegorická a mytologická plátna erotické povahy. Kromě produkce svých dvorních umělců sbíral práce proslulých mistrů, k nimž patřili Jan van Eyck, Raffael Santi, Leonardo da Vinci, Correggio, Parmigiano, Tintoretto a Tizian (Hausenblasová - Šroněk 1997). Jeho sběratelské ambice se odrazily $\mathrm{v}$ početném sbírkovém souboru výtvarných artefaktů a uměleckých děl v privátních prostorách Pražského hradu. Skladba pražských sbírek Rudolfa II. - kunstkomory a obrazové galerie, odpovídala osobnímu zájmu císaře a současně reflektovala akviziční činnost pověřených specializovaných agentů. Tito umělečtí prostředníci realizovali nové akvizice v podobě rozmanitých artefaktů i výtvarného umění za účelem rozšíření sbírky i zapojení umění do státní reprezentace (Kneidl 1989; Fučíková 1997). Kolekci Rudolfa II. lze přibližně rekonstruovat na základě několika dochovaných inventářů. $\mathrm{V}$ průběhu třicetileté války byla kolekce nenávratně narušena a na českém území zůstala pouze v reliktech (Brožková a kol. 1983). Nemohla se proto stát základem pozdějšího muzea nebo galerie, jako tomu bylo např́klad v př́padě kunstkomory Rudolfova strýce arcivévody Ferdinanda II. (1529-1595) na zámku Ambras u Innsbrucku (Špét 2003; Putová 2016).

V 50. letech 17. století se na obnově obrazárny Pražského hradu podílel rakouský arcivévoda Leopold I. Vilém (1614-1662), jenž během svého působení v Bruselu získal stovky italských, španělských, nizozemských a německých děl. Celkem vlastnil na 40 Tizianových obrazů. Zčásti se jeho díla získaná v Bruselu ocitla ve Vídni a zčásti v Praze (Berger 1883). Plátno Toaleta mladé ženy je patrně zachyceno v obraze Leopold Vilém ve své 
obrazárně v Bruselu (kolem 1651). Jeho tvůrcem je David Teniers mladší (1610-1690), který zastával pozici dvorního malíře i správce bruselských sbírek Leopolda I. Viléma (Sterling 1998). Plátno Toaleta mladé ženy ovšem Teniers ztvárnil nedůsledně; schází polička, lahvička i hřeben a místo zrcadla jsou na pozadí provedeny iniciály V V P značící VECELLIUS VENETUS PINXIT. Mladého muže s hladkou tváŕí ztvárnil bez turbanu. O tom, že se plátno Toaleta mladé ženy nedostalo do Vídně, však vypovídá jeho absence v inventáři z roku 1659 (Wethey 1975). V roce 1685 je v inventáři Pražského hradu evidováno na 551 obrazů. Mezi nimi se nachází i plátno Toaleta mladé ženy uvedené jako Tizianův originál. To přetrvává i v letech 1718 a 1737 (Köpl 1889, 1891). V roce 1782 je však již označeno jako anonymní. V letech 1832 a 1838 je následně připsáno Oraziovi (kolem 1528-1576), synovi Tiziana. V roce 1860 se stává opět dílem anonymního mistra, tentokrát však kladené do souvislosti s plátnem Toaleta mladé ženy z Louvru. V inventáři z let 1880-1944 je plátno explicitně označeno jako kopie tohoto díla (Morávek 1937). Ještě v roce 1910 zůstává anonymním plátnem. Tizianovo autorství je $\mathrm{s}$ jistotou uváděno až od druhé poloviny 20. století (Neumann 1966).

\section{LITERATURA}

Angeloglou, Maggie (1973): A History of Make-Up. New York: Macmillan.

Berger, Adolf (1883): Inventar der Kunstsammlungen des Erzherzogs Leopold Wilhelm von Österreich aus dem Jahre 1659. Jahrbuch der kunsthistorischen Sammlungen des Allerhöchsten Kaiserhauses in Wien 1-2, LXXIX-CLXXVII.

Bertamini, Marco - Latto, Richard - Spooner, Alice (2003): The Venus Effect: People's Understanding of Mirror Reflections in Paintings. Perception 32, 593-599.

Brown, David Alan - Ferino-Pagden, Sylvia (Eds.), (2006): Bellini, Giorgione, Titian and the Renaissance of Venetian Painting. New Haven: Yale University Press.

Brožková, Helena a kol. (1983): Sběratelství. Praha: Svoboda.

Castiglione, Baldessare (1978): Dvořan. Praha: Odeon.

Cropper, Elizabeth (1976): On Beautiful Women, Parmigianino, Petrarchismo, and the Vernacular Style. Art Bulletin 58, 374-394.

Cropper, Elizabeth (1986): The Beauty of Women: Problems in the Rhetoric of Renaissance Portraiture. In Ferguson, Margaret W. (Ed.), Rewriting the Renaissance: The Discourse of Sexual Difference in Early Modern Europe. Chicago: Chicago University Press, 175-190.

Fučíková, Eliška (Ed.), (1997): Rudolf II. a Praha: Císařský dvůr a rezidenční město jako kulturní a duchovní centrum střední Evropy. Praha: Správa Pražského hradu.

Genders, Roy (1972): Perfume Through the Ages. New York: Putnam.

Goffen, Rona (1997): Introduction. In Goffen, Rona (Ed.), Titian's Venus of Urbino. Cambridge: Cambridge University Press, 1-22.

Goffen, Rona (1999): Crossing the Alps: Portraiture in Renaissance Venice. In Aikema, Bernard (Ed.), Renaissance Venice and the North: Crosscurrents in the Time of Bellini, Dürer and Titian. Milan: Bompiani, 114-131.

Gunn, Fenja (1973): The Artificial Face: A History of Cosmetics. London: David \& Charles.

Hagen, Rainer - Hagen, Rose-Marie (2002): What Great Paintings Say II. Köln: Taschen.
Hausenblasová, Jaroslava - Šroněk, Michal (1997): Urbs Aurea: Praha císaře Rudolfa II. [Praha]: Gallery.

Chojnacki, Stanley (1990): Marriage Legislation and Patrician Society in Fifteenth Century. In Nicholas, David - Bachrach, Bernard S. (Eds.) Law, Custom, and the Social Fabric in Medieval Europe: Essays in Honor of Bryce Lyon. Michigan: Western Michigan University, 163-184.

Christel, Dominik (2011): Žena a zrcadlo: Proměny zobrazení ženy ve vztahu $k$ motivu zrcadla a fenoménu optické reflexe. Diplomová práce. Masarykova Univerzita, Filozofická fakulta, Brno.

Kaminski, Marion (1998): Tiziano Vecellio, Know as Titian: 1488/1490-1576. Köln: Könemann.

Kneidl, Pravoslav (1989): Počátky sběratelství a strahovský kabinet kuriozit. Praha: Památník národního písemnictví.

Köpl, Karl (1889): Urkunden, Acten, Regesten, und Inventare aus dem k. k. Statthalterei-Archiv in Prag. Jahrbuch der kunsthistorischen Sammlungen des Allerhöchsten Kaiserhauses 10, LXIII-CC.

Köpl, Karl (1891): Urkunden, Acten, Regesten, und Inventare aus dem k. k. Statthalterei-Archiv in Prag. Jahrbuch der kunsthistorischen Sammlungen des Allerhöchsten Kaiserhauses 12, I-XC.

Maser, Edward A. (Ed.), (1991): Cesare Ripa: Baroque and Rococo Pictorial Imagery. The 1750-60 Hertel Edition of Ripa's Iconologia with 200 Engraved Illustrations. Toronto: Dover Publications.

Melchior-Bonnet, Sabine (2001): The Mirror: A History. New York: Routledge.

Meyers, Diana T. (2002): Gender in the Mirror: Cultural Imagery and Women's Agency. Oxford: Oxford University Press.

Morávek, Jan (1937): Sbirky Rudolfa II.: pokus o jich identifikaci. XII. výstava Musea hlav. města Prahy, spolu s Archivem pražského hradu, březen-květen 1937. Praha: Nákladem Kuratoria Musea hlav. města Prahy.

Neumann, Jaromír (1966): Obrazárna Pražského hradu: soubor vybraných děl. Praha: Academia.

Neumann, Jaromír (1976): Pocta Tizianovi: $k$ 400. výročí úmrtí, výstava, Národní galerie v Praze, Okresní národní výbor v Kroměřiži, Československá komise pro spolupráci s UNESCO Praha, Královský letohrádek, prosinec 1976-únor 1977. Praha: Národní galerie.

Pardo, Mary (1993): Artifice as Seduction in Titian. In Turner, James (Ed.), Sexuality and Gender in Early Modern Europe. Cambridge: Cambridge University Press, 55-89.

Petrarca, Francesco (1965): Sto sonetů Lauře. Praha: Státní nakladatelství krásné literatury a umění.

Putová, Barbora (2016): Tiziano e la collezione di Rodolfo II. Titian and the Collection of Rudolf II. In Puppi, Lionello - Baccaglina, Serena (Eds.), Tiziano, Vanitas. Il Poeta dell'Immagine e l'Ombra della Bellezza. Titian. The Poet of the Image and the Shade of Beauty. Milan: Silvana Editoriale, 85-98.

Simons, Patricia (1995): Portraiture, Portrayal and Idealization: Ambigous Individualism in Representations of Renaissance Women. In Brown, Alison (Ed.), Language and Image of Renaissance Italy. Oxford: Clarendon 263-311.

Sterling, Charles (Ed.), (1998): Fifteenth- to Eighteenth-Century European Paintings: France, Central Europe, The Netherlands, Spain, and Great Britain. New York: The Metropolitan Museum of Art.

Špét, Jiří (2003): Přehled vývoje českého muzejnictví I. (do roku 1945). Brno: Masarykova univerzita v Brně.

Tinagli, Paola (1997): Women in Italian Renaissance Art. Manchester: Manchester University Press.

Tour d'Albenas, Bérenger de la (1953): Le Miroir. In Poèmes du XVIe siècle. Paris: Gallimard, 353.

Turner, Joseph Mallord William (1802): Titian and his Mistress. In: Studies in the Louvre Sketchbook, D04300, D04301; Turner Bequest LXXII. London: Tate Gallery.

West, Shearer (Ed.), (2004): Portraiture. Oxford: Oxford University Press.

Wethey, Harold E. (1975): The Paintings of Titian III.: The Mythological and Historical Paintings. London: Phaidon. 
